between pure research and applied research; there is only science and use of science." In my own words, the distinction between basic and applied research is more one of attitude than of approach.

The conclusion I draw from the foregoing considerations is that a new source of research funding and, more important, of challenges, is being opened to universities by the emergence of the academic-industrial complex. It provides the prospect of universities making contributions to the peace-time prosperity of America comparable to those they made to its war-time defense in the 1940s. There remains only for us academicians to make the overtures to our industrial counterparts and, with them, to plan how we can proceed beneficially in consort.

John F. Kennedy

\title{
ON SECOND ThOUght, I THINK WE SHOUlD KeEP THESE COLLEGES GOING
}

\section{I}

On second thought, I think we should keep these colleges going. Take myself. I testify. First, the grounds are beautiful and the Iowa River can shake a soggy day into wonder. If the mountains here are subtle, the Iowa sky is the biggest pair of wings around. And love can go a long way on the plains to find what it needs.

I testify. I admit failure and doubt. Schooling has the faults of human beings. I have taught entire years without once apprehending the whole thing, the main thing or the first thing. For the lesson of the humanities may be that yesterday's lesson is no lesson at all. Pindar asked, "What are we? What are we not?" No wonder we envy the birds their "get up and go." No wonder we fill our yards with visible age and full flowering. But still there isn't another growing thing on this rocky apple in the skies which tries to distinguish truth from convention. Not even a fox. Not even an owl.

\section{$\mathrm{O}$}

Now comes the time when everyone wants something from the birds, from the trees. 
From the sky.

Now comes the time when everyone wants something.

Someone wants better weather,

someone hopes for a look at the future

or the past. In the University,

it's "Condition Now." It is not that wishing,

wanting or hoping

to be elsewhere, it is not a separate world.

W

I won't mention winter, except to say that a snowy Sunday is the best of it, when the cars pad by and the mind itself seems a clean slate on which one might write again, with that wonder and apprehension one remembers from first grade, the secret symbols of adulthood, when the leaves themselves signal that weight, that specific gravity which is the grown-up's and which is all in the head. We who are the University each year begin our work again in the fall, which may be lusher elsewhere but is no more various than here in Iowa.

We were never good machines, we humans. We pasted our research on every public post and tree to be followed. We smudged the boundaries of our studies to better indicate our hearts. We took sides, we upset the applecart, we made our mistakes alone and in groups. Why should we be less sinuous, less flexible, less freely articulated than the animals? The mind is not a curse. It has its ideas. It is open to suggestion. It wants to use the freedom it has imagined for itself. It wants to be tougher than a fullback, more various than the fall. It wants to re-define the poem, and everything else. It fixes itself on change: uh oh. It watches the technical but it watches the humane. It is all of us, this school, this town, and instantly anyone who comes here. Now, while the trees, mindless or mindful we aren't sure, finish dropping their leaves, we have a mind to, we have a need to, we have a heartfelt desire to say, with our weighty hands as we sit in ceremony, with our minds which have anticipated you and given you a place, and with our hearts in which we locate all 
that we mean when we say a little: Welcome, President James O. Freedman. Damn happy it's you.

Marvin Bell 